\title{
Dynamic Statutory Interpretations and Sluggish Social Movements
}

\author{
Brett McDonnell $\uparrow$
}

This Comment argues that civil rights activists have focused too many resources on attempting to gain favorable statutory interpretations in court rather than pursuing changes in Congress. Though in some circumstances a judicial strategy may lead to greater short-run gains, it is less likely to change preferences in the long run. The Comment makes this argument using a modified version of William Eskridge's game-theoretic model of the interaction between the Court, Congress, and the President. It also adds a second period to the game, with a legislative strategy more likely to shift preferences leftward in the second period. The Comment applies the theory to the Civil Rights Act of 1991, arguing that the 1989 Supreme Court decisions which provoked the Act may have helped civil rights activists by prodding them to return to activism focused on Congress. It concludes by suggesting that, in the present environment, a mass action strategy focused on changing long-run preferences rather than immediately changing the law either in the courts or in Congress might be most effective.

\section{INTRODUCTION}

Political progressives frequently go to court to achieve their aims. Since Brown v. Board of Education, ${ }^{1}$ this has seemed a natural strategy. It finds contemporary expression in Baehr v. Lewin, ${ }^{2}$ the Hawaii samesex marriage case. However, going to court requires resources that might otherwise be spent on such things as lobbying legislators or grassroots mobilizing. These different strategies have different prospects

Copyright $\odot 1997$ California Law Review, Inc.

$+\quad$ Law clerk to the Honorable Alex Kozinski, United States Ninth Circuit Court of Appeals. B.A. 1985, Williams College; M.Phil. 1988, Emmanuel College, Cambridge; Ph.D. 1995, Stanford University; J.D. 1997, Boalt Hall School of Law, University of California, Berkeley. I thank Professor Daniel Rodriguez for his guidance and comments and the editors and members of the California Law Review, especially Tom Ginsburg, for all their work and help. Above all, 1 thank my domestic partner and best friend, Paul Rubin, for reading this many times and making helpful comments each time.

1. 349 U.S. 294 (1955).

2. 852 P.2d 44 (Haw. 1993). 
for success in the short run. They also have different long-run prospects for changing the preferences of voters and politicians. This Comment argues that activists concentrating on short-run gains in court have lost broader social support im the long run.

A court challenge often involves disputes over interpreting statutes. Progressives tend to prefer expansive interpretations that update statutes to reflect contemporary values and understandings, whereas conservatives believe the court is an inappropriate forum to pursue social change. ${ }^{3}$ Legal theorists who support progressive judicial interpretations must articulate a theory underlying such activism.

A leading contemporary exponent of such a theory is William Eskridge. In a series of papers culminating in the 1994 book Dynamic Statutory Interpretation, ${ }^{4}$ Eskridge revitalized scholarly work on interpreting statutes. He argues that courts rely in part on their own understanding of policy im interpreting statutes, rather than simply divining the intent of the enacting legislature. He also analyzes how the preferences of the current legislative and executive branches constrain judicial decisions by threatening overrides. Eskridge sees statutes as evolving to take into account changed circumstances and the current values of the Court, Congress, and the President. He calls this "dynamic statutory interpretation," and provides various reasons why it is desirable. ${ }^{5}$ One motivation underlying his project may be to promote court decisions that advance progressive social causes, in contrast with the textualist rhetoric and conservative tendencies of the Rehnquist Court. ${ }^{6}$

Work in other areas of legal scholarship, however, suggests that relying on courts is not always a wise strategy for social movements. Soine have even questioned the granddaddy of social change cases, Brown $v$. Board of Education, ${ }^{7}$ arguing that legislation and administrative action were needed to effect change, and that courts played little role in encouraging that legislation. ${ }^{8}$ Might it be that the Warren Court's practice of dynamic statutory interpretation seduced activists into litigationbased strategies that in the long run have enervated them and reduced their impact? To the extent that activists face a tradeoff between short-run gains in court and bigger gains in the long run through political mobilization, too often civil rights activists have opted for the

3. Of course, this may be a relic of decades where the Supreme Court tended to be liberal. Attitudes may be changing as the conservative reign on the Court continues.

4. William N. Eskridge, JR., DyNamic Stituturo Interpretation (1994).

5. See id. at $48-80$.

6. Eskridge's work is interspersed with examples from many cases. A number of these involve civil rights issues. See, e.g., id. at 298-305 (discussing Wards Cove Packing Co. v. Atonio, 490 U.S. 642 (1989)); id. at 240-73 (discussing Patterson v. McLean Credit Union, 491 U.S. 164 (1989)).

7. 349 U.S. 294 (1955).

8. See, e.g., Gerald N. Rosenberg, The Hollow Hope $42-71$ (1991). 
former. Thus, the hostile Rehnquist Court may be an unexpected boon, if it forces activists back to the grassroots.

I shall advance this argument within the framework of Eskridge's article Reneging on History? ${ }^{9}$ Using simple game theory, his essay sets up a positive and normative framework for analyzing Supreme Court civil rights decisions in recent decades and the reactions to them by Congress and the President. ${ }^{10}$ Game theory deals with strategic interactions where the acts of each person depend on what they expect others to do. It depicts persons and organizations as rational self-interested actors trying to achieve the best possible outcome, given how they predict others will react to their choices. ${ }^{11}$ The cool logic of this theory may seem an unlikely tool to apply to the politically and symbolically heated area of American racial politics and the courts. However, rational choice theory has been useful in thinking about many areas of social life and may be able to generate msights into this issue.

In Eskridge's model, the Court first chooses how to interpret a statute, then Congress chooses whether to rewrite the statute to reflect its own preferences rather than the Court's. ${ }^{12}$ If Congress passes a bill, the President then chooses whether to sigu or veto it. If the President vetoes, Congress may override the veto. The Court has its own preferences as to how it would like to interpret legislation, but it is aware that if it goes too far, Congress and the President may pass new legislation overturning the Court's result. The Court therefore only goes as far in its preferred direction as it thinks it can without provoking a response.

Eskridge uses this theory to explain the outcome of civil rights cases in three different eras, which essentially correspond to the Warren, Burger, and Rehnquist Courts. Eskridge posits different Court, Congressional, and Presidential preferences for each period, then uses the model to explain judicial outcomes given these preferences. Eskridge's story is imteresting and illuminating, but ironically not as "dynamic" as it might be. His theory does nothing to explain how political preferences change from one period to another. Nor does it explore how political choices in one period might affect future preferences.

Activists comparing judicial versus legislative strategies for change must ask not only what each strategy can accomplish in the near future, but also how each strategy will affect political mobilization, general public attitudes, and the resulting long-rnn preferences of the President,

9. William N. Eskridge, Jr., Reneging on History? Playing the Court/Congress/President Civil Rights Game, 79 CaLIF. L. REv. 613 (1991).

10. See id. at 642-83.

11. See generally ERIC RASMUSEN, Games AND INFORMATION (1989) (explaining game theory).

12. See Eskridge, supra note 9 , at 643-44. 
members of Congress, and the Court. Perhaps a judicial strategy leads to short-run gains when the current Court is receptive, but does little to change the attitudes of the public and politicians. If so, using the judiciary to pursue social change will lead to less long-run change than would more grassroots approaches. Using a more dynamic form of Eskridge's theory will allow us to consider this argument.

I propose to complicate Eskridge's model in several ways. First, I add a new player, political activists, who choose whether to focus on pursuing results in court or in Congress. Second, I present a model with two periods, not one. Activists, the Court, Congress, and the President all make their decisions in one period, resulting in judicial interpretation and possibly a new statute. Then, perhaps after a change in preferences of the actors, they repeat this in the second period. Using a two-stage model complicates the analysis by making actors consider the effects of their present actions on future outcomes. Third, I make several sets of preferences endogenous to the model. ${ }^{13}$ I postulate that different forms of political mobilization have different effects on citizens, among other things affecting their preferences concerning civil rights laws. Present political choices in turn affect the future preferences of the political actors: Congress, the President, and the Supreme Court.

To make the discussion more concrete, I shall apply the general theory to the Civil Rights Act of 1991, which overturned a number of Supreme Court cases. ${ }^{14}$ I shall particularly focus on two of the overturned cases: Patterson v. McLean Credit Union ${ }^{15}$ and Wards Cove Packing Co. v. Atonio. ${ }^{16}$

The argument that follows is somewhat complex. In Part II, I set out the historical background underlying the Civil Rights Act of 1991. In Part III, I explain Eskridge's theory from Reneging on History? and how he applies it to understanding the series of related Court opinions and Congressional reactions. Part IV lays the basis for extending Eskridge's theory by examining ways in which different strategies followed today may affect future preferences. Judicial, legislative, or mass action strategies change future institutional preferences via several routes. For one, they may affect the beliefs, preferences, and mobilization of civil rights supporters. Part IV.A sketches a theory of how civil

13. Preferences in the second period are determined within the model, rather than being accepted as given and determined by forces wholly outside the model.

14. See Civil Rights Act of 1991, Pub. L. No. 102-166, 105 Stat. 1071 (codiffed in scattered sections of 42 U.S.C.).

15. 491 U.S. 164 (1989).

16. 490 U.S. 642 (1989). 
rights supporters ${ }^{17}$ overcome the free-rider problem $^{18}$ to mobilize politically in supporting civil rights laws. Part IV.B considers the mobilization of opponents of civil rights laws and of public opinion generally. Part IV.C examines how citizens' opinions and actions are transformed into the preferences of political actors (Congress, the Court, and the President). Though more empirical research is required, legislative or mass action strategies appear more likely to change future preferences than a judicial strategy. Part V modifies Eskridge's formal theory to analyze a two-period model: civil rights proponents follow either a judicial or a legislative strategy for changing a law in the first period; the first period outcome leads to new preferences on the part of Congress, the President, and the Court via the mechanisms discussed in Part IV, with a legislative strategy more likely to lead to more liberal preferences than a judicial strategy. The new preferences lead to a new outcome in the second period.

Part VI applies this model to the Civil Rights Act of 1991 and to civil rights politics today. Eskridge thinks the congressional override of many decisions shows the Rehnquist Court has not played the Court/Congress/President game well. The dynamic theory suggests several alternative stories. One possibility is that the Court's recalcitrance has forced advocates to go back to more grassroots Congressional lobbying, strengthening their long-run political position and leading to stronger laws than they would have achieved under a more sympathetic Court. This would not have been the Court's intent, but rather an unanticipated effect of the judicial decisions. An alternative interpretation is that the Court's actions contributed to a changed political environment on racial issues, leading in the long run to national policies closer to its conservative preferences. Either way, with today's conservative Court, a judicial strategy might actually make the law more conservative than the status quo in the short $\mathrm{mn}$, and might threaten to make future preferences even more conservative. Even a legislative strategy might be futile in the short run. Thus, today a mass action strategy aimed primarily at shaping future preferences makes the most sense.

17. At points, this Comment particularly focuses on blacks as a major subset of civil rights supporters. The United States contains more racial minorities than just blacks, but this Comment is already complicated enough, and this simplification should not be too damaging for the issues at hand.

18. The free-rider problem occurs when a good, such as improved civil rights laws, can help many persons simultaneously, and it is not possible to exclude those benefits from persons who have not helped to achieve the good. In such a situation, each person would like the good, but would prefer that everyone but them bears the cost of providing it. If too many people "free ride" and do not contribute to the good, the good will not be provided. See MANCur OLson, The Logic of Collective Action 21 (197I). 
II

The Civil Rights Act of 1991

The Civil Rights Act of 1991 was a dramatic legislative override of Supreme Court jurisprudence in the civil rights area. It overturned several major civil rights decisions from 1989, which had seemed at the time like major defeats for civil rights activists. However, these "defeats" prodded those activists back to the legislative sphere to lobby for a stronger law than the activists could have achieved in court. The 1991 Act is thus a case study in the benefits of choosing a legislative strategy over a judicial one. This Section provides historical background on the Act and the cases it overturned.

The story begins with the Civil Rights Acts of $1866,{ }^{19}$ a central part of the Reconstruction Congress's attempt to secure the rights of freed black slaves. Section 1 of the Act stated

[t]hat all persons born in the United States and not subject to any foreign power... are hereby declared to be citizens of the United States; and such citizens, of every race and color, without regard to any previous condition of slavery or involuntary servitude ... shall have the same right, in every State and Territory in the United States, to make and enforce contracts, to sue, be parties, and give evidence, to inherit, purchase, lease, sell, hold, and convey real and personal property, and to full and equal benefit of all laws and proceedings for the security of person and property, as is enjoyed by white citizens, and shall be subject to like punishment, pains, and penalties, and to none other, any law, statute, ordinance, regulation, or custom, to the contrary notwithstanding. ${ }^{20}$

The property portion of section one is currently codified as 42 U.S.C \& $1982 .^{21}$

In the Civil Rights Cases of 1883, the Supreme Court said in dictum that the Act applies only to state action. ${ }^{22}$ After this decision, the issue of applying the old Civil Rights Acts to private discrimination largely disappeared from case law until the 1960s. Congress outlawed private discrimination in employment in the Civil Rights Act of $1964^{23}$ and private discrimination in housing in Title VIII of the Civil Rights Act of $1968 .{ }^{24}$

Following these new laws, the Supreme Court returned to the issue of whether the nineteenth-century Act could be applied to private

19. Civil Rights Acts, ch. 31,14 Stat. 27 (codified as amended at 42 U.S.C. $\$ \S 1981-1982$ (1994)).

20. Id. at $\S 1$.

21. See Jones v. Alfred H. Mayer Co., 392 U.S. 409, 412 (1968).

22. See Civil Rights Cases, 109 U.S. 3, 10-11 (1883).

23. See 42 U.S.C. $\$ \S 2000 \mathrm{e}$ to $2000 \mathrm{e}-17$ (1994).

24. See Civil Rights Act of 1968, Pub. L. No. 90-284, 82 Stat. 81 (1968). 
discrimination. ${ }^{25}$ It first faced this question in 1968 in the area of housing in Jones $v$. Alfred H. Mayer Co. ${ }^{26}$ The argument for a broad interpretation of $\S 1982$ won in Jones, and for the first time the Court deemed the nineteenth-century Civil Rights Act to apply to private discrimination. ${ }^{27}$ In later cases, the Court followed this precedent and said $\S$ 1981 also applies to private discrimination. ${ }^{28}$

This is where the law stood when the Court decided Patterson $v$. McLean Credit Union, ${ }^{29}$ a case involving racial harassment at work. In that case, the Court created a ruckus by asking for reargument on the issue of whether $\S 1981$ should apply to private discrimination. ${ }^{30}$ Eventually, the Court stuck with precedent on stare decisis grounds. ${ }^{31} \mathrm{How}-$ ever, it limited the scope of this line of cases by saying the right to make and enforce contracts does not extend to harassment after being hired. The Court reasoned that $\S 1981$ gives blacks "the same right ... to make'... [and] 'enforce contracts." "32 According to the Court, the statute's reference to making contracts refers to contract formation, not to what happens thereafter. Enforcing contracts refers to the "protection of a legal process." 33 Harassment at work falls under neither of these categories. A promotion can only be construed as making a new contract if "the nature of the change in position was such that it involved the opportunity to enter into a new contract with the employer," but not otherwise. ${ }^{34}$

The 1991 Civil Rights Act overturned this result. Congress first tried to pass the Act in 1990, but President Bush vetoed that version and Congress narrowly failed to override the veto. ${ }^{35}$ Following the outcry in response to the Thomas/Hill hearings, a similar bill passed in 1991. This time President Bush sigued it. ${ }^{36}$ The new Act deliberately overturned Patterson by adding a sentence to $\S 1981$ that says "[f]or purposes of this section, the term 'make and enforce contracts' includes the making, performance, modification, and termination of contracts, and the

25. Using the old Act in some cases benefits plaintiffs in terms of the procedures or remedies available.

26. 392 U.S. 409 (1968).

27. See id. at 413 .

28. See Runyon v. McCrary, 427 U.S. 160, 168 (1976); Johnson v. Railway Express Agency, Inc., 421 U.S. 454, 459-60 (1975); Tillman v. Wheaton-Haven Recreation Ass'n, Inc., 410 U.S. 431, 439-40 (1973).

29. 491 U.S. 164 (1989).

30. See Patterson v. McLean Credit Umon, 485 U.S. 617, 617 (1988).

31. See 491 U.S. at 175.

32. Patterson, 491 U.S. at 176.

33. Id. at 177.

34. Id. at 185.

35. See Timothy D. Loudon, The Civil Rights Act of I991: What Does It Mean and What Is Its Likely Impact?, 71 NEB. L. REv. 304, 306 (1992).

36. See id. at 307. 
enjoyment of all benefits, privileges, terms, and conditions of the contractual relationship." 37 The Act also codified the private action interpretation of $\S 1981$ by adding "[t]he rights protected by this section are protected against impairment by nongovernmental discrimination and impairment under color of State law." ${ }^{38}$

The other major case overturned by Congress in the 1991 Act was Wards Cove Packing Co. v. Atonio. ${ }^{39}$ This case limited the disparateimpact line of cases interpreting Title VII of the 1964 Act that began with Griggs v. Duke Power Co. ${ }^{40}$ Title VII provides that it shall be an unlawful employment practice for an employer

(2) to limit, segregate, or classify his employees ... in any way which would deprive or tend to deprive any individual of employment opportunities or otherwise adversely affect his status as an employee, because of such individual's race, color, religion, sex, or national origin....

(h) Notwithstanding any other provision of this subchapter, it shall not be an unlawful employment practice for an employer... to give and to act upon the results of any professionally developed ability test provided that such test, its administration or action upon the results is not designed, intended or used to discriminate because of race, color, religion, sex or national origin..$^{41}$

In Griggs, the Court held the plaintiff need not prove that the defendant intends to discriminate by following a particular practice, but only that the practice has a disparate inpact. To defend the practice, the employer must show it is "demonstrably a reasonable measure of job performance." $\$ 42$

Wards Cove made it harder for plaintiffs to prove disparate impact. First, it required that plaintiffs presenting statistical evidence of disparate impact compare the racial coinposition of the individuals enployed in the jobs at issue with the racial composition of qualified persons in the job market, not that of the general population. ${ }^{43}$ The plaintiff must also show that each specific disputed employment practice has a discriminatory impact. ${ }^{44}$ Critics complained this would often pose a daunting statistical task. ${ }^{45}$

37. Civil Rights Act of 1991 § 101(b), 42 U.S.C. § 1981(b) (1994).

38. Id. at $\$ 101(c), 42$ U.S.C. $\S 1981(c)$.

39. 490 U.S. 642 (1989).

40. 401 U.S. 424 (1971).

41. 42 U.S.C. § $2000 e-2(a)(2)$, (h) (1994).

42. Griggs, 401 U.S. at 436.

43. See Wards Cove, 490 U.S. at 650-51.

44. See id. at 657 .

45. See Jesse A. Witten, Recent Development, 13 Harv. JL. \& Pub. PoL'y 383, 393-94 (1991). 
Once the plaintiff has presented a prima facie case showing a disparate impact, the defendant may argue that the practice is nonetheless justified. The language on this point is ambiguous in Griggs. At one point it says " $[t]$ he touchstone is business necessity. If an employment practice which operates to exclude Negroes cannot be shown to be related to job performance, the practice is prohibited." "Necessity" and "related" are quite different standards. Later in Griggs, the Court says practices are permissible only if "they are demonstrably a reasonable measure of job performance." 47 Does "a reasonable measure" mean one related to job performance? Does it mean one necessary to job performance? Is it somewhere in between? One cannot tell by reading Griggs. Later decisions vacillated between these two standards. ${ }^{48}$

Under the Wards Cove formulation, the defendant must show that the challenged practice "serves, in a significant way, the legitimate employment goals of the employer." ${ }^{\text {"49 }}$ The Court was concerned that a stronger standard would be overly difficult for employers to meet and would encourage them to drop useful employment practices or institute racial quotas to avoid suit. The Court also shifted the burden of persuasion in this justification stage from the employer to the plaintiff, though the employer retained the burden of production..$^{50}$

In its most controversial provisions, the Civil Rights Act of 1991 overturned parts of the Wards Cove decision. Had these sections, and a few others, not been included, the 1990 bill would have passed easily. There was little controversy over many portions of the Act, including that which overturned Patterson. However, overturning Wards Cove was different. President Bush opposed the portion of the Act purporting to reinstate the business necessity requirement, saying it would force employers to institute racial quotas. ${ }^{51}$ The original Democratic version of the 1990 bill defined business necessity as "essential to effective job performance." 52 The final conference report defined it as "a significant relationship to successful performance of the job." ministration's preferred language was "a significant relationship to a significant business objective." ${ }^{34}$ Despite the closeness of their positions,

46. Griggs, 401 U.S. at 431.

47. Id. at 436 .

48. See Andrew M. Dansicker, A Sheep in Wolf's Clothing: Affirmative Action, Disparate Impact, Quotas and the Civil Rights Act, 25 Colum. J.L. \& Soc. Probs. 1, 19 (1991).

49. Wards Cove Packing Co. v. Atonio, 490 U.S. 642, 659 (1989).

50. See id.

51. See Bush Vetoes Rights Bill, Objects to "Quotas," 48 CoNG. Q. WKLY. REP. 3654 (1990) (President Bush's message on vetoing the $1990 \mathrm{Act}$ ).

52. Dansicker, supra note 48 , at 28-29.

53. Id. at 29 (quoting S. 2104,101 st Cong. $\$ 3(1990)$ ).

54. Id. at 30 . 
the two sides could not agree. ${ }^{55}$ The successful 1991 Act left "business necessity" undefined, though it instructed courts to use pre-Wards Cove cases in defining the term. ${ }^{56}$ Given the ambiguity in those cases, this command is not very helpful. The Civil Rights Act of 1991 also shifted the burden of persuasion on the business necessity defense back to the defendant, and said that if in proving the prima facie case it is impossible to disentangle the effects of several practices, the plaintiff could group those practices in proving a disparate impact. The Act did not overturn the section of Wards Cove requiring plaintiffs to look to the racial composition of the relevant job market as a point of comparison. ${ }^{57}$

The Act went beyond reversing Court decisions, adding new protections for civil rights plaintiffs such as compensatory and punitive damages in Title VII cases. ${ }^{58}$ It also provided for jury trials on request in intentional discrimination cases. ${ }^{59}$ These significant extensions of Title VII could only have been achieved by legislative action because the 1964 Act left no room for court interpretation on these points.

All of these cases overturned in the 1991 Act show a Supreme Court prone to narrow, conservative readings of civil rights laws and a Congress willing to revise the law in a more expansive, liberal direction. Our questions concern what this history tells us about the interaction

55. It is not at all clear that there is any real difference between the opposing language. For a discussion of the possible legal consequences of the altemative language and of the underlying political conflict, see $i d$. at 30-31.

56. See Civil Rights Act of 1991 § 105(b), 42 U.S.C. § 2000e-2(k)(1) (1994).

57. The Civil Rights Act of 1991 also overtumed several other 1989 Supreme Court decisions. Martin v. Wilks, 490 U.S. 755 (1989), allowed white firefighters who were not parties to a consent decree to challenge it, leading to fears of continual court challenges to such dccrees. The 1991 Act overruled Wilks by barring two groups from challenging a consent decree in employment cases: those who had notice and an opportunity to join the case, and those whose interests were adequately represented in the original judgment. See Civil Rights Act of $1991 \S 108$. Lorance $v$. AT\&T Technologies, Inc., 490 U.S. 900 (1989), held the statute of limitations on a discriminatory seniority system tolls when the system was adopted, not when it hurts the plaintiff. The Act tolls the statute of limitations when the system is adopted, when the plaintiff becomes subject to the system, or when the plan hurts the plaintiff. See Civil Rights Act of 1991 § 112. Price Waterhouse v. Hopkins, 490 U.S. 228 (1989), held that where an employer has both a discriminatory and a legitimate motive in an employment decision, the employer is not liable if she proves by a preponderence of the evidence that she would have made the same decision without the illegitimate motive. The Act provides that if the plaintiff proves a discriminatory motive, no simultaneous legitimate motive can remove liability. See Civil Rights Act of $1991 \S 107($ a). However, if the employer can show she would have made the same decision without the illegitimate motive, the court cannot award damages or issue an order requiring reinstatement, hiring, or promotion. See id. at § 107(b). EEOC v. Arabian American Oil Co., 499 U.S. 244 (1991), held Title VII does not cover American citizens outside U.S. jurisdiction but employed by U.S. corporations. The Act extended coverage to such persons. See Civil Rights Act of 199I $\S$ I09. The Act also reversed West Virginia Univ. Hosp., Inc. v. Casey, 499 U.S. 83 (1991), which held that expert witness fees are not recoverable in civil rights cases. See Civil Rights Act of $1991 \$ 1 \mathrm{I} 3$.

58. See Civil Rights Act of $1991 \S 102$.

59. See id. at $\S 102(\mathrm{c})$. 
between Congress, the President, and the Court and about wise strategies for expanding civil rights laws.

III

\section{Eskridge's Version of the Court/Congress/President Game}

In 1991, William Eskridge applied his theory of dynamic statutory interpretation to the conflict between Congress, the President, and the Court over these civil rights statutes, among others. ${ }^{(0)}$ He used a gametheoretic model to analyze how the Court has interpreted civil rights statutes to promote its own values, constrained by the possible responses of Congress and the President. In this Part, I describe his model and point to where it may be expanded.

The Court, the President, Congress, and congressional committees all have preferences on civil rights issues which Eskridge arrays along a one-dimensional left-right continuum. Points further left represent preferences for stronger civil rights legislation. ${ }^{61}$ For the multiperson actors (i.e., all but the President), the most preferred point of the median member determines the actor's preference. ${ }^{62}$ The Court would like to come as close as it can to its most preferred interpretation, but must take into account the possibility of an override by Congress and the Presideut.

Eskridge has the Court move first, interpreting a statute as falling somewhere on the left-right continuum. Congress deliberates over whether to override the Court's interpretation. A gatekeeping committee would have to introduce a bill to Congress or the Court's interpretation will stand. If the committee introduces a bill, the full Congress may amend that bill to take the position it wants. ${ }^{63}$ 1f the bill passes Congress, the President may sign or veto. If the President vetoes, Congress may override by a two-thirds vote. ${ }^{64}$

For 1962-71, Eskridge posits preferences as shown in Figure $1 .^{65} \mathrm{P}$ and $\mathrm{C}$ are the most preferred points of the President and the Court, which are to the left of $M$, the most preferred point of the median member of Congress. This reflects the fact that Congress, especially the southern-dominated Senate, was more conservative on civil rights issues than the Warren Court or Presidents Kennedy or Johnson. G is the preferred point of the relevant congressional committee, or gatekeeper, and

\footnotetext{
60. See Eskridge, supra note 9.

61 See id. at 643.

62 See id.

63. This model thus assumes the open rule, where committee versions may be amended on the floor. See id. at $643-44$.

64. The model assumes a unicameral Congress. See id. For our purposes, the interaction between the House and Senate is not important enough to include in the model.

65. See id. at 646.
} 
$\mathrm{G}(\mathrm{M})$ is the point at which the gatekeepers are indifferent between that point and $M$. Thus, for any point $X_{1}$ to the left of $G(M)$, the Committee prefers $M$ to $X_{1}$. The gatekeepers are relevant because they can block legislation from reaching the floor if they think the end result will be worse than the status quo. ${ }^{66}$

\begin{tabular}{cccccc}
1 & 1 & 1 & 1 & 1 & 1 \\
\hline$X_{1}$ & $G(M)$ & $P, C$ & $G$ & $M$ & $X_{2}$
\end{tabular}

Figure I

If preferences were as shown, the Court could choose any point between $G(M)$ and $M$ without fear of being overruled. If the Court took a position to the left of $G(M)$, such as $X_{1}$, the gatekeepers would introduce a bill overriding the interpretation, and the President and Congress would be able to agree on a point between $P$ and $M$ which both prefer to $X_{1}$. Thus, the Court would be overruled. If the Court took a position to the right of $M$, such as $X_{2}$, again Congress and the President would be able to agree on a point they prefer between $M$ and $P$, overruling the Court. If the Court chooses a point between $G(M)$ and $M$, however, the Committee will block any new bill, because the result in Congress (M) would be worse from the Committee's point of view than the Court's interpretation. ${ }^{67}$ As drawn, the Court is free to choose its most preferred point, C. Note that this is to the left of what Congress would prefer.

This could well be what happened in 1968, when the Court extended $\S 1982$ to private discrimination in housing in Jones $v$. Alfred $H$. Mayer $\mathrm{Co} .^{68}$ The Court probably went beyond what would have emerged in 1866,1964 , or 1968 had Congress directly and clearly legislated on the issue. ${ }^{69}$ However, there was enough support within Congress and from the President that the Court's position could not be overruled. In 1972, Senator Roman Hauska proposed an amendment to the Equal Employment Opportunity Act of 1972 that would have made Title VII and the Equal Pay Act the exclusive remedies for einployment discrimination. The amendinent passed in the House, failed on a tie vote in the Senate, and was not adopted in the Conference Committee. ${ }^{70}$ Something similar may well have happened with Griggs v. Duke Power Co."

66. See id. at 645 .

67 See id. at 646.

68. 392 U.S. 409 (1968); see supra text accompanying note 27.

69. See Jones, 392 U.S. at 478 (Harlan, J., dissenting) ("In effect, this Court, by its construction of $\S 1982$, has extended the coverage of federal 'fair housing' laws far beyond that which Congress in its wisdom chose to provide in the Civil Rights Act of 1968.").

70. See Eskridge, supra note 9, at 648.

7I 401 U.S. 424 (1971). 
By the eighties, relative preferences had shifted with the election of a conservative Republican President and the buildup of Nixon, Ford, and Reagan appointees on the Court. Congress was now to the left of the President and the Court. Eskridge sees the situation as shifting to Figure $2 .^{72}$

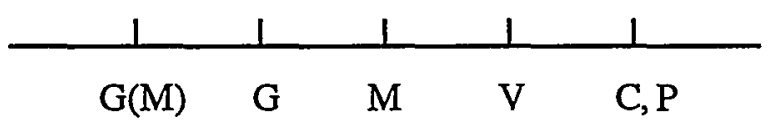

Figure 2

This figure adds a new point, $\mathrm{V}$, which is the point at which two-thirds of Congress has ideal points to the left of and including V. Were the Court to set a point to the right of $\mathrm{V}$, Congress could overturn it with a new law at V; the President would then veto the bill, but Congress would override it. ${ }^{73}$ Were the Court to set a point to the left of $G(M)$, the committee would introduce a new bill and $M$ would be the result. The President would sign this, since it is closer to $P$ than the Court's interpretation. Thus, the Court can now choose any point between $G(M)$ and $\mathrm{V}$ without being overruled. ${ }^{74}$

Eskridge thinks that in 1989 the Court tried to come as close to V as possible. In 1990, it looked like the Court had found the right point, with the override of the President's veto of the 1990 version of the Act falling one vote short in the Senate. However, in 1991, Congress overturned the decisions. This goes counter to the theory, and Eskridge has several possible explanations. ${ }^{75}$ First, there may have been uncertainty as to exactly where V lay, and the Court may have been off in its guess. ${ }^{76}$ Perhaps the intervening 1990 elections changed the preferences of Congress. ${ }^{77}$ Or, the Thomas/Hill hearings may have changed the political calculus, making many politicians nervous about appearing insensitive

72. See Eskridge, supra note 9, at 653 .

73 See id. at 653.

74. Between $G(M)$ and $M$, the committee will not introduce a bill. Between $M$ \& $V$, the committee may introduce and Congress may pass a bill at $\mathrm{M}$, but the President would veto and Congress would be unable to ovcride.

75. Although the 1991 Act had not passed at the time Eskridge wrote, he expected that a number of the 1989 Court cases would be overturned or revised in Congress. See Eskridge, supra note 9 , at 655 .

76. See id. Eskridge finds this explanation problematic because it does not explain why the Court was especially poor at guessing during this period as opposed to earlier ones.

77. This does not appear correct, however. Though Democrats did make gains in the 1990 elections, the anti-affirmative action advertisements Jesse Helms used to win re-election received much attention and appear to have made members of Congress more cautious on civil rights issues. For much of 1991, the Civil Rights Act did not appear likely to pass. See, e.g., Joan Biskupic, With Business Talks Stalled, Bush Holds Best Hand, 49 CoNG. Q. WKLY. Rep. 1063 (1991). 
to the concerns of minority and especially women voters. ${ }^{78}$ Second, Eskridge suggests an informational version of the model. ${ }^{79}$ This version sees the Court as trying to provide useful information to the Congress about the effects of laws. The Court cannot be sure how the Congress will use this information, so legislative overrides will sometimes occur. ${ }^{80}$

In either version, Eskridge thinks that the Rehnquist Court has been overruled on civil rights issues so often that it is not playing the game very well. He suggests that after the 1991 Act the Court may choose to become less aggressive in its statutory interpretations, or else Congress may be provoked to take more drastic measures to hold back the Court. ${ }^{81}$

Despite the name "dynamic statutory interpretation," Eskridge's analysis is not particularly dynamic. He sees the actors playing a oneperiod game ${ }^{82}$ against each other, taking preferences as given. Over time the preferences of both citizens and political actors shift through social change, elections, and appointments. As a result, the interpretations of the statutes change. However, in Eskridge's model, those changes in preferences are exogenous.

The changes may actually be partly endogenous. Court decisions may affect public opinion, which may in turn eventually affect the positions of Congress and the President. Similarly, political mobilization to change a law may change the views of political actors. Over a long period, the political branches' dissatisfaction with the Court may lead to appointments which change the view of the Court. Such long-term effects should be of interest for the theory of statutory interpretation. Moreover, insofar as the actors themselves take into account these future effects, their present behavior may change, leading to different predictions for the theory.

78. The momentum appears to have swung to the Civil Rights Act only after the Thomas/Hill hearings, according to contemporary accounts. See, e.g., Pamela Fessler et al., Rights Bill Rises from the Ashes of Senate's Thomas Fight, 49 CoNG. Q. WKLY. REP. 3124 (1991).

79. This may not be consistent with having the committee and Congress separate as in Figures 1 and 2. See infra note 118 and accompanying text.

80. See Eskridge, supra note 9, at 656-59.

81. See id. at $662-63$. One possibility is that the Court could become more conciliatory on issues of statutory interpretation and instend push its civil rights agenda in constitutional cases, in which overruling Court decisions is much more difficult. This may partially explain recent cases such as Shaw v. Reno, 509 U.S. 630 (1993), Miller v. Johnson, 115 S. Ct. 2475 (1995), and Adarand Constructors, Inc. v. Pena, 115 S. Ct. 2097 (1995), in which the Court used interpretations of the Equal Protection Clause to reach conservative positions on civil rights issues. Of course, with the advent of a Republican-controlled Congress, the Court may now be freer to pursue conservative interpretations.

82. In a one-period game, actors make their moves as defined above, considering only the consequences at the end of that one set of moves. Actors do not take into account that they may move again in the future, when present outcomes may have affected future possibilities. 
These somewhat abstract concerns may make a real difference in how we interpret the politics of the Civil Rights Act of 1991. On the one hand, though civil rights proponents like Eskridge tend to condemn the Court's decisions, perhaps the Court helped the long term health of the civil rights movement. The cases limiting civil rights remedies arguably turned activists' attention toward Congress and the President. If this strategy ultimately does more to move future preferences in a pro-civil rights direction than do sympathetic Court opinions, then the Courtsupplied imcentives forcing civil rights organizations into a large-scale mobilization may have helped them, resulting in a nore progressive law after 1991 than liberal Court decisions would have created.

On the other hand, though the Court nnay have lost a battle, perhaps it has not lost the war. The 1989 cases, Wards Cove in particular, and the political battle in 1990 and 1991, may have focused more public attention on civil rights and allowed Republicans to label Democrats as supporters of quotas. If this ultimately sways public opinion against expansion of civil rights remedies, the preferences of the Court and President Bush may yet prevail. Current debate over affirmative action, including the resolutions of the University of California Board of Regents and the California Civil Rights Initiative, suggests this possibility. ${ }^{83}$

The remainder of this paper elaborates and applies a dynamic extension of Eskridge's theory. In doing so, it presents a simple twoperiod model, in which action in the first period affects the preferred points of the various actors in the second. It then applies this model to the politics of the Civil Rights Act of 1991. Before doing so, I examine the factors that may affect these inter-period changes. The preferences of Congress and the President will reflect the underlying struggle between proponents and opponents of civil rights legislation, mediated through political institutions. Parts IV.A and IV.B look at how different political strategies will affect the beliefs and mobilization of potential proponents and potential opponents. Part IV.C considers how beliefs and political mobilization become reflected in the preferences of Congress, the President, and the Court.

\section{IV}

\section{How Present Political Action Affects Future Preferences}

The institutional preferences and behavior of Congress and the President can be pictured as the result of an interaction between forces affecting the demand for and supply of political behavior. Citizens

83 See, e.g., Jeffrey B. Wolff, Comment, Affirmative Action in College and Graduate School Admissions-The Effects of Hopwood and the Actions of the U.C. Board of Regents on Its Continued Existence, 50 SMU L. REv. 627, 654-59 (1997). 
mobilize to support and oppose political change, and politicians must decide how to respond to these forces. The demand side results from organized action for and against political measures. The supply side results from how elected officials respond to the demand-side factors. ${ }^{84}$ Parts IV.A and IV.B analyze the demand side (citizen mobilization). Part IV.C analyzes the supply side (the behavior of politicians).

\section{A. Mobilizing Support for Civil Rights}

Like all large groups, civil rights supporters face a collective-action problem in mobilizing support for civil rights. Each individual has an incentive to free ride, a problem extensively analyzed in literature beginning with Mancur Olson's landmark book, The Logic of Collective Action. ${ }^{85}$ Potential civil rights supporters in the U.S. make up a large enough group that, in a simple version of Olson's theory, collective action should be impossible. Yet, civil rights supporters have managed to mobilize, more effectively at some times than others. Dennis Chong has begun analyzing how American blacks have overcome the free-rider problem. ${ }^{86}$ In this Part, I review that analysis and consider how the analysis might look different for mass movements, legislative lobbying, and litigation, ${ }^{87}$ with the end goal of considering how different strategies might differeutly affect the preferences of Congress, the President, and the Court.

Chong focuses mainly on mass social action such as occurred in the sixties. This type of action generates the most pressure on political institutions, but is also the hardest to create and sustain. Marches, boycotts, and sit-ins are familiar tactics of such action. They require the physical participation of large numbers of people to be effective in generating publicity, one of the main ways in which such tactics pressure political institutions.

Why do people participate in such action? There may be various expressive benefits to participation. ${ }^{88}$ Social action allows participants to express deeply held beliefs. Successful action may increase participants' self-esteem and may provide a sense of excitement at being a part of

84. See Matthew L. Spitzer, Antitrust Federalism and Rational Choice Political Economy: A Critique of Capture Theory, 61 S. CAL. L. REv. 1293, 1303 (1985); WILLIAM N. ESKRIDGE, JR., \& Philip P. Frickey, Cases and Materials on Legislation 53-56 (1988).

85. Ouson, supra note 18.

86. See Dennis Chong, Collective Action and the Civil Rights Movement (1991). Chong focuses on blacks, not civil rights supporters generally. Not all blacks support the positions of mainstream civil rights organizations, and many supporters of those positions are not black. However, it is important to the political economy of civil rights that blacks support civil rights advances, since the existence of a black community creates the potential for strategies which can surmount the freerider problem.

87. Chong does not distinguish among the thrce as I do and largely focuses on mass movements.

88. See Chong, supra note 86, at 73-89. 
history.$^{89}$ Some may feel morally obliged to participate. ${ }^{90}$ Repeated social interaction outside the movement among potential participants is an important source of motivation. ${ }^{91}$ If group members approve of becoming involved, then gaining a reputation for being active may give one prestige among the people with whom one interacts regularly. One may also simply enjoy working with one's friends on a common, important goal.

Note two important aspects of many of these motivations, both of which are crucial to Chong's analysis. First, the benefits from participating increase as more people participate. Social action then comes to resemble an "assurance game" in game theory such that cooperation with others is individually beneficial for each participant if and only if the others cooperate as well. ${ }^{92}$ Second, achieving some success also helps increase the benefit from participating. The prestige and improved reputation from being associated with a movement are generally greater if it is a successful movement. ${ }^{93}$

These two features create a boom-and-bust tendency for mass social action. They create a positive feedback mechanism: success and the involvement of many people tend to bring in more people, and so on. Successful movements feed on their success. On the other hand, once a movement starts to falter, it may spiral downward. It is also quite hard to start a movement in the first place. ${ }^{94}$ Mass action is risky and requires a heavy expenditure of resources by activists. However, it also yields a potentially high payoff in dramatic political pressure.

At the other end of the spectrum of types of activism is litigation. This does not require the personal involvement that mass action does. Instead, it relies on the efforts of a small number of lawyers and people helping them, and most of these people are compensated (monetarily) for their efforts. ${ }^{95}$ Some people do have to pay for the lawyers, and that may involve a free-rider problem. ${ }^{96}$ Why should I pay for a civil rights lawyer when I can let my neighbor do it? However, since fewer people need be involved, there is less personal risk, and since there is some benefit from an award of damages, the problem is therefore more easily

89. See Russell Hardin, Collective Action 108-12 (1982).

90. See id. at 106.

91. See ChONG, supra note 86, at 34-37; see also HaRdin, supra note 89 (disussing contract by convention). This is a major reason why the existence of a black community is critical to the politics of civil rights.

92. See Chong, supra note 86 , at $31-72$.

93. See id. at 148.

94. See generally id. at 191-229 (describing the rise and fall of social movements).

95. However, they generally are not compensated at anywhere near the rate they could earn in other pursuits.

96. Plaintiffs do capture some benefits through damages paid. Insofar as the precedent value of a case helps future plaintiffs, though, there is an externality that individual plaintiffs do not capture. 
overcome. On the other hand, the psychic and social benefits from this sort of impersonal involvement may well also be less. The social benefits of participation are certainly less. The expressive benefits of giving money are presumably also less than those from marching or engaging in a sit-in. Litigation is a low-maintenance, low-energy form of action in comparison to mass movements.

In general, one would expect such action to have less effect on members of Congress and the President. Politicians will feel less pressure from their liberal constituents under a litigation-based strategy, both because those constituents do less to try to communicate with their representatives, and because litigation does less to educate constituents as to how to vote and less to motivate them to make civil rights issues important in deciding for whom to vote. The politicians will also learn less about the need for improved protections of minorities.

However, there are at least three ways in which civil rights litigation could help increase the mobilization of civil rights supporters. First, where the Court is more inclined to be receptive to civil rights arguments than Congress or the President, litigation may provide more hope of some immediate success. We have seen that the prospect of success is important in motivating people to participate in social action. Some have argued that courts played a major role in spurring social action by providing some hope of change. ${ }^{97}$

Second, once civil rights supporters achieve some success in court, they may be even more willing to fight attempted rollbacks than they were to fight for the gain in the first place. It is an accepted notion that political programs are harder to defeat once installed than before they are adopted..$^{98}$ Part of the strong reaction to the 1989 Court cases may have been due to the perception that the Court was taking back gains already won.

Third, the infrastructure for litigation may help in legislative lobbying. The NAACP is at the center of both forms of action in the civil rights movement. Expertise in litigation may carry over to some degree into expertise in lobbying-lawyers are crucially involved in both.

Legislative lobbying is a third alternative that lies between mass social action and litigation. It does not require the heavy personal involvement of many people as in mass action. However, it requires more than simply giving money, and it probably requires more money than litigation. Writing letters to politicians and newspapers, making phone

97. See, e.g., Stephen L. Carter, Do Courts Matter?, 90 MiCH. L. REv. 1216, 1221 (1992). But see ROSENBERG, supra note 8 , at 155-56.

98 See, e.g., Eugene Bardach, Policy Termination As A Political Process, reprinted in William N. Eskridge, Jr. \& Philip P. Fricke, Cases and Materials on Legislation 852, 853-54 (1988). 
calls, and attending meetings are typical aspects of lobbying that resemble the broad-based nature of mass demonstrations but have the direct focus of litigation.

The personal benefits from lobbying also probably lie between the benefits of the other two forms of action. Taking part in lobbying produces more self-expressive benefits than simply contributing money to legal efforts. Lobbying groups may also be more social than groups focused simply on legal strategies. On the other hand, lobbying presumably provides less intense psychological benefits than mass action. Similarly, lobbying activities are less social and involve fewer people than mass action.

Lobbying is directly aimed at members of Congress and the President and likely tends to have a greater direct effect on their preferences than litigation. Of course, the success of a legislative strategy depends in part on how much money civil rights groups can raise. Civil rights lobbying groups do not tend to be well funded compared to many other interest groups. However, they may have an influence beyond their funds, because politicians know they represent many voters. Voting is a low-cost form of political action, ${ }^{99}$ so if civil rights lobbying groups can succeed in influencing their constituents' votes, groups like the NAACP will have political influence beyond what their funding level might suggest. ${ }^{100}$

Thus, of the three ways of mobilizing support for civil rights discussed here, mass action potentially has the greatest effect on society and perhaps on Congress and the President, but it is hard to initiate, requires the most resources, and may be unstable. Litigation-based activism requires the fewest resources, but mobilizes fewer people, and seems less likely to have a direct effect on Congress and the President. Legislative lobbying falls between the two.

\section{B. Mobilizing Opposition to Civil Rights}

The last sub-Part considered how three different political strategies might mobilize support for enhancing civil rights protections. This subPart considers the opposition to such measures. There are two important potential sources of such opposition: business and mass opinion. I analyze them separately, starting with business.

Businesses are very often the defendants in civil rights cases, especially employment cases like those discussed earlier in this article, and

99. Economic theory still does not explain well why so many people vote when they have little chance of making any difference in the outcome. See DANIEl A. FARBER \& PhILIP P. FRICKEY, LAW AND Public ChoIce 25 (1991).

100. See, e.g., Donald Wittman, Why Democracies Produce Efficient Results, 97 J. PoL. EcoN. 1395 (1989). 
therefore have reason to oppose the strengthening of civil rights laws. Business groups are a potent source of political opposition; a large percentage of interest groups in American politics represent business interests. ${ }^{101}$

However, those groups tend to represent particular industries, not business as a whole. The exceptions, such as the Chamber of Commerce and the Business Roundtable, tend not to be as well organized. ${ }^{102}$ Standard free-rider theory explains this--business as a whole is a much larger group than particular industries, and there is less frequent interaction between any two random businesses than between two in the same industry. ${ }^{103}$ To the extent that civil rights legislation and cases threaten business, they threaten it as a whole, not any particular industry. Thus, theoretically it is unclear how much opposition to civil rights advances business groups will mount.

How do the three types of civil rights political strategies-mass mobilization, legislative lobbying, and litigation-affect business opposition? If activists follow a litigation-based strategy, businesses, particularly larger corporations, tend to have the resources to defend themselves in court, though they inay often prefer to settle rather than fight for their preferred interpretations of the statutes. If activists follow a mass action strategy, businesses are unlikely to respond with mass action of their own. If, however, either mass action or legislative lobbying results in bills, business groups may respond, depending on the incentives for business mobilization discussed above. For instance, business groups were central to the opposition to the Civil Rights Acts of 1990 and 1991. In 1990 they won; in 1991 they lost, though they won compromises or victories on soine points.

The other main potential source of opposition to civil rights advances is mass public opinion. The focus here is particularly on the opinion of whites-whites still provide a majority of the votes in the United States, and provide an even higher percentage of opponents to civil rights measures. As a very large, diverse group, whites as a whole should face a severe free-rider problem in generating political mobilization. On the other hand, white voters dominate most American elections, and are thus of central interest to politicians if whites are motivated to vote in part by concern over civil rights issues, and if they are motivated in the same direction.

In figuring out motivation on racial issues, it seems that the positive political theory methodology underlying most of this Comment has some use, but also serious limits. Positive political theory, with its

101. See OLson, supra note 18 , at 141.

102. See id. at 145-46.

103. See, e.g., id. 
emphasis on self-interested individual motives, does explain both the tendency of many whites to oppose civil rights laws and the difficulty in mounting sustained white opposition. It does not explain the success of white opposition through much of American history. Nor does the theory do well in explaining why many whites now support some versions of civil rights laws as the right thing to do.

I shall make the working hypothesis that most white Americans have an individualistic vision of racial justice. ${ }^{104}$ They desire a society in which each individual has an equal opportunity to achieve. They are more skeptical of notions of group entitlement. These notions are vague, though, and they are intermixed with individual self-interest and racism, both overt and subconscious racial stereotyping. Another important factor is information-many whites may know little either about the effects of racism on blacks or about how politicians vote on racial issues.

How do the three different political strategies (mass movements, legislative lobbying, and litigation) affect these attitudes, and thereby the likelihood that whites will act on their beliefs? All three can have mixed effects. A major point of mass action is to stir the public conscience and expose whites to the extent of the gap between racial reality and aspirations, giving them more information. To some extent the civil rights movement accomplished this, especially in the early sixties. ${ }^{105}$ The growing adoption of Martin Luther King, Jr. as a modern civic saint is evidence of this. On the other hand, a mass movement can provoke fear and backlash. This was true in the late 1960s, when state and local governments sought to repress the civil rights movement. ${ }^{106}$ By making racial issues more salient, it can give those white voters opposed to civil rights more information about how their representatives vote.

Litigation-based activism is less drainatic, but does it still affect white opinion? Empirical evidence is hard to find. Some say that progressive Court opinions helped push whites toward greater acceptance of change, and thus paved the way for the civil rights bills of the sixties. ${ }^{107}$ Others fear that the countermajoritarian tendencies of the Warren Court threatened to undermine the Court's legitimacy. ${ }^{108}$ Still others think the

104. See Gunnar Myrdal et al., AN American Dilemma 3-25 (1962).

105. See, e.g., Aldon Morris, Centuries of Black Protest: Its Significance for America and the World, in RACE IN AMERICA 19, 50, 56 (Herbert Hill \& James E. Jones, Jr. eds., 1993).

106. See id. at 53 .

107. See, e.g., Jack Greenberg, The Supreme Court, Civil Rights and Civil Dissonance, 77 YALE LJ. 1520, 1521-22 (1968).

108. See, e.g., Alexander M. Bickel, The Least Dangerous Branch 257-58 (2d. ed. 1986). 
Court has little effect at all. ${ }^{109}$ This is a critically important area for future empirical research. ${ }^{110}$ It seems most likely that the Court has little effect on public opinion most of the time, or at least a weaker effect than could be achieved through other forms of political action. ${ }^{\prime \prime \prime}$

Legislative lobbying may also have ambiguous effects on the white public. Insofar as lobbying is done in part through public media using a message that appeals to the basic individualistic ethos, it may encourage white support for new civil rights laws. Also, if successfully passed laws have an educative and legitimating effect, legislative lobbying may increase white support. On the other hand, if whites perceive the lobbying as merely advancing a special interest, it may not have the desired effect on white attitudes and beliefs. For whites opposed to civil rights measures, legislative lobbying may make them better informed as to how their representatives vote. Though empirical evidence on this question is scarce, it is likely that mass action and legislative lobbying generally affect public opinion more strongly than judicial decisions. If it is hotly debated whether even the most famous decision of the twentieth century, Brown v. Board of Education ${ }^{I / 2}$, significantly affected public opinion, lesser opinions probably have a weak effect or no effect at all.

\section{The Political Process}

The last two sub-Parts described the demand-side effects of various civil rights strategies. This sub-Part considers the supply side and possible outcomes. By the supply side, I mean how political actors-the President, Congress, and the Court-respond to the strategies and to the resulting behavior of their constituents. ${ }^{13}$

As is common in positive political theory analysis, I presume that members of Congress and the President pursue their own re-election, ${ }^{114}$ though there may be some slack that allows them to pursue personal preferences as well. ${ }^{115}$ Their ultimate goal is votes, and a very important

109. See, e.g., Rosenberg, supra note 8, at 155-56; Richard Delgado \& Jean Stefancic, The Social Construction of Brown v. Board of Education: Law Reform and the Reconstructive Paradox, 36 WM. \& MARY L. REv. 547, 550-51 (1995).

110. See, e.g., Christopher L. Eisgruber, Is the Supreme Court an Educative Institution?, 67 N.Y.U.L. REV. 961 (1992).

111. For some support of this position from a seasoned group of court observers, both scholars and practitioners, see Remedial LAW 71-73 (Robert C. Wood cd., 1990).

112349 U.S. 294 (1955).

113. See Spitzer, supra note 84; ESKRIDGE \& FRICKEY, supra note 84.

114. There are more or less venal justifications for this assumption, but there is also a Darwinian argument: politicians who do not pursue the goal of maximizing their chances of re-election are less likely to be re-elected, and hence they disappear from the corridors of power. $C f$. Spitzer, supra note 84, at 1306-07 (arguing that voters choose politicians for how well their actions meet expectations).

115. For example, the role of Republican Senators John Danforth and William Cohen in passing the 1991 Act. On Danforth, see Joan Biskupic, Danforth's Persistence Paid Off In Thomas, Civil Rights Battles, 49 CONG. Q. WKLY. REP. 3202 (1991). Cohen said, vis-a-vis the Act, that "[p]olitical 
tool for garnering votes is money. In examining how the demand-side factors of the last two Parts affect politicians, we must consider their effects on votes and money.

As to votes, in the U.S. there are many more whites than blacks, potentially imperiling civil rights gains if they become black-versuswhite issues. However, several forces can, under some circumstances, create more votes for politicians who support civil rights than for those who oppose them. First, civil rights supporters may feel stronger about the issue than opponents, so that they vote based on a candidate's civil rights record or promises, whereas opponents do not. Supporters may also know more about a candidate's civil rights record than opponents do. Second, many whites may support civil rights laws as just, whether or not they are in their narrow self-interest. Thus, a key strategy for winning votes in Congress and the White House is to persuade and inform blacks to vote for pro-civil rights politicians, while convincing sympathetic whites that the cause is just and not angering other whites enough that these issues decide their votes.

Though mass movements, legislative lobbying, and litigation have ambiguous effects on voter mobilization, mass movements probably do the most to generate pro-civil rights votes. Legislative lobbying also can effectively generate civil rights votes, though these effects are likely to be less strong than with mass movements. Litigation is least likely to affect votes.

Money also influences politicians. Organized civil rights groups give political donations, but they do not give particularly large amounts. No major organized groups today are specifically devoted to opposing civil rights. However, business groups oppose many specific civil rights measures aimed at employment, and business groups dominate political contributions. For most controversial measures affecting employment, civil rights groups can expect to be outspent. They need to be able to convince politicians that their relative effectiveness in imfluencing votes is strong enough to outweigh their inability to fill campaign coffers.

Another factor to consider on the supply side is the structure of Congress. Structure-induced equilibrium has become a major topic in positive political theory. ${ }^{116}$ Committees act as gatekeepers: if they oppose a bill, it generally will not reach the floor. This function of committees is already built into Eskridge's model described in Part III above and will reinain iu the expanded model of the next Part. The

success ought to mean something more than he who dies holding the most votes." Fessler, supra note 78, at 3126.

116. For references and discussion, see FARBER \& FRICKEY, supra note 99, at 50. Structureinduced equilibrium simply refers to the way that particular procedural structures in politics can reduce the number of possible equilibrium outcomes that positive political theory predicts. 
relevant committees for civil rights tended to be to the left of the median member of Congress in the mid-sixties through early nineties, though committee opposition was a major hurdle for the Civil Rights Act of $1964 .{ }^{117}$ It is hard to say whether the various activist strategies considered here are likely systematically to affect committee preferences differently than they do congressional preferences generally. It may be that the members on committees dealing with civil rights are selfselected for their strong views on the subject. It may also be that the smaller number of people on committees as compared with Congress as a whole allows interested groups to focus resources on committee members and win them to their side.

A different approach to congressional committees sees them as feeders and processors of information. On this view, the preferences of committees tend to be close to those of the full Congress rather than outliers pulled to extremes by special interests. ${ }^{118}$ Legislative lobbying may focus on committees not so much to win over members via influence as to give them information which they can process and pass on to the full Congress.

It is less clear how different political strategies affect Supreme Court preferences. Writers in law and economics and positive political theory have grappled with the problem of explaining influences on judicial preferences, with at best lukewarm success. ${ }^{119}$ Re-election is not the goal of Supreme Court justices. Unless they have an eye on the Chief Justiceship, promotion is not a goal either. At least to some degree, justices' votes reflect their ideological beliefs. In the area of civil rights, individual justices seem to have general visions that are consistent across most votes. ${ }^{120}$ These generally reflect the views of the Presidents who appointed them, ${ }^{121}$ though there are exceptions, such as Justices Earl Warren, William Brennan, and, it would increasingly seem, David Souter.

Both judicial and legislative strategies give justices information about how laws will function. This information inay affect their beliefs about which interpretations are best. A judicial strategy gets information to the justices directly via the cases that they hear. A legislative strategy works more indirectly, via the media, other general sources of information, and the legislative history justices use in deciding cases.

It is thus difficult to say how the different political strategies affect the long-run preferences of the Court. Presumably judicial strategies are

117. See, e.g., Charles Whalen \& Barbara Whalen, The longest Debate 40-41, 64-66 (1985). But see Eskridge, supra note 9, at 649.

118. See Keith Krehirid, Information and Legislative Organization 123 (1991).

119. See Richard A. Posner, Overcoming Law 112-13 n.7 (1995).

120 See John E. Nowak, The Rise and Fall of Supreme Court Concern for Racial Minorities, 36 WM. \& MARY L. REV. 345 (1995).

121. See id. at 359. 
relatively more effective with the Court than with Congress or the President, since justices are more heavily exposed than elected politicians to the information revealed through a judicial strategy. It is unclear whether mass movements or legislative lobbying have any direct effect on the justices, though if they care about their reputations, there might be some effect. There is a longer-run effect, though, as changes in the President and Congress eventually become reflected in the views of newly appointed justices.

The theory developed in these three sub-Parts differs significantly from the standard story of United States v. Carolene Products $\mathrm{Co}^{122}$ as developed by John Hart Ely. ${ }^{123}$ In the standard story, blacks are a minority shut out from political power. White prejudice compels white voters into passing racist laws, or at least into ignoring black interests. Social isolation leads to political isolation. In my story, it is possible that this very isolation may lead to political strength, as civil rights supporters are able to overcome the free-rider problem and organize to pass favorable laws, while potential opponents stand aside because of the collective-action problem.

I am not the first to point out that Carolene Products' focus on "discrete and insular"124 minorities may be suspect on a positive political theory analysis. Bruce Ackerman made a similar point a decade ago. ${ }^{125} \mathrm{He}$ used this argument to suggest that diffuse groups, such as women or gays, may be more politically vulnerable than racial minorities or other discrete groups. ${ }^{126}$ The idea that some civil rights legislation may be due to traditional interest group pressure has also found its way into a few Supreme Court opinions, such as Justice Stevens' dissent in Fullilove v. Kutznick, ${ }^{127}$ Justice Scalia's dissent in Johnson $v$. Transportation Agency, ${ }^{128}$ and Justice O'Connor's opinion in Richmond v. J.A. Croson Co. ${ }^{129}$

These arguments do not unambiguously indicate that blacks are a powerful special interest group, however. Civil rights supporters face a major collective-action problem. If they fail to solve it, lack of political pressure combined with pressure from business groups may create a hostile political environment. Furthermore, legislation may reflect in part the personal preferences and prejudices of mostly white politicians,

\footnotetext{
122. 304 U.S. 144 (1938).

123. See John Hart Ely, Democracy and Distrust 152-53 (1980).

124. 304 U.S. at $152-53$ n.4.

125. See Bruce A. Ackerman, Beyond Carolene Products, 98 HARv. L. Rev. 713, 718 (1985).

126. See id. at 742 .

127. See 448 U.S. 448, 541-42 (1980) (Stevens, J., dissenting).

128. See 480 U.S. 616,677 (1987) (Scalia, J., dissenting).

129 See 488 U.S. 469,495 (1989).
} 
to the extent that a particular legislative vote is not determinate of future election outcomes.

On the opposing side, conservative whites face an even more significant collective-action problem. If civil rights issues become prominent enough, they may provoke such whites to base their votes in part on a candidate's civil rights stance, and anti-civil rights sentiment would then dominate most U.S. elections. Daniel Farber and Philip Frickey have criticized the Ackerman and Scalia critique of Carolene Products, arguing that prejudice still works against blacks in American politics, and that various opponents of black progress still have plenty of clout. ${ }^{130}$

The truth about black political power probably lies somewhere in between these competing viewpoints. With each issue and each point in time, we need a careful, fact-specific analysis of the underlying politics to understand which of the many possible factors dominated.

In sum, mass action has the strongest effect on mobilizing support for civil rights laws, though it requires more social resources to start and sustain. Litigation has the weakest effect, and a legislative strategy is inbetween. As for provoking opposition to civil rights laws, mass action by civil rights supporters probably has the strongest effect, though it may win over some opposition as well. The greater political mobilization under mass action is likely to affect Congress and the President more quickly than the Court. Thus, mass action is likely to move future institutional preferences in a direction favoring civil rights laws, with the effect being least strong on the Court. Litigation has the least strong probability of affecting future preferences, and legislative lobbying falls in between mass action and litigation.

\section{V}

\section{A Two-Period Model of the Court/Congress/President Game}

The last Part analyzed various factors that may affect the preferences of political actors in Eskridge's model. This Part presents a simple extension of that model, taking into account these effects. In this version, activists can choose to pursue their preferred rule either through a judicial interpretation, which the Congress may then choose to overrule, or by going to Congress directly to seek legislation. For the sake of simplicity, I have dropped mass action as a third option. At the level of generality of this simple model, mass action and legislative lobbying do not look much different. The model has two periods, and activists repeat their choice between a judicial or legislative rule in each period. The strategy activists choose to follow in the first period probabilistically

130 See Daniel A. Farber \& Philip P. Frickey, Is Carolene Products Dead? Reflections on Affirmative Action and the Dynamics of Civil Rights Legislation, 79 CAL1F. L. REv. 686, 687-89, 709 (1991). 
affects the preferences of the President and Congress in the second period.

In each period, preferences of the median member of Congress (M), the committee or gatekeeper (G), the President (P), and the Court (C) are arrayed along a single dimension, with more leftward positions signifying more liberal views on civil rights. The committee is indifferent between $G(M)$ and $M$ (so that to the left of $G(M)$ the committee prefers $M)$. SQ represents the status quo if no bill is passed and the Supreme Court does not decide on the subject. ${ }^{131}$ If activists choose a judicial strategy $(J)$, the Court then announces a position, and Congress may overrule this if it can. I shall assume that, within a period, the Court behaves strategically so that it chooses a point as close as possible to its preferences while avoiding being overruled by Congress.

\begin{tabular}{lllllll}
$L$ & $\perp$ & $\perp$ & $\perp$ & $\perp$ & $\perp$ & $\perp$ \\
\hline$C$ & $G(M)$ & $G$ & $M$ & $S Q$ & $V$ & $P$
\end{tabular}

Figure 3

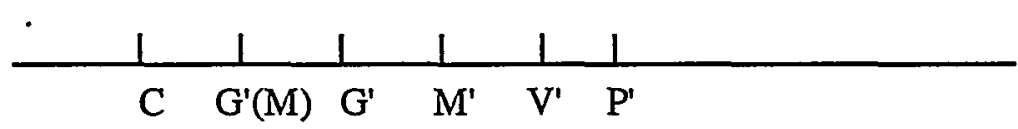

Figure 4

Let us assume preferences are as in Figure 3 and that activist preferences are to the left of $C .{ }^{132}$ Because the Court's preferences lie so far to the left, a judicial strategy might seem effective. ${ }^{133}$ Any interpretation between $G(M)$ and $V$, which is the point at which two-thirds of each house of Congress have ideal points to the left of and including V, will not be overruled. To the left of $G(M)$, the committee would be willing to introduce legislation, knowing that Congress would move to $M$, and the President would sign this. To the right of $\mathrm{V}$, Congress would pass $\mathrm{V}$. Given Court preferences as in Figure 3, the strategic Court would choose $\mathrm{G}(\mathrm{M})$.

131. It is necessary to add SQ in order to determine the outcome under a Iegislative strategy.

132. Figure 3, following Eskridge, has committee preferences (G) well to the left of Congress (M), reflecting a view of committees as self-selected and special targets of interest groups. See Eskridge, supra note 9, at 646, 650,653.

133. Were preferences as in Figure 2, a judicial strategy would make little sense: a legislative strategy would lead to better short- and long-run outcomes. This ignores the possibly higher cost of a legislative strategy, which I discuss briefly below. 
Alternatively, activists could follow a legislative strategy (L). With SQ as pictured, a bill could pass through the committee, would not be vetoed by the President, and $M$ would be the resulting outcome. Thus, for one period on these preferences, a judicial strategy gives better results for the activists because $G(M)$ is closer to their preferences than is M.

Let us now add a second period. In the second period, institutional preferences may remain the saine as in Figure 3. However, they may instead shift to positions as in Figure 4, with $\mathrm{C}$ unchanged but all the other preferences shifted left. ${ }^{134}$ Preferences will shift as in Figure 4 with some probability, but that probability depends on the strategy followed in the first period, for reasons discussed in the last Part. The shift occurs with probability $\mathrm{p}_{\mathrm{L}}$ if activists follow strategy $\mathrm{L}$, and with probability $\mathrm{p}_{\mathrm{J}}$ if they follow strategy $J .^{135}$ The assumption $\mathrm{p}_{\mathrm{L}}>\mathrm{p}_{\mathrm{J}}$ captures the effects discussed in Part IV. ${ }^{136}$

Activists could follow one strategy in period 1 and another in period 2. The four possible strategies are $(\mathrm{L}, \mathrm{L}),(\mathrm{L}, \mathrm{J}),(\mathrm{J}, \mathrm{L})$, and $(\mathrm{J}, \mathrm{J})$, the first letter representing the strategy chosen in the first period and the second letter the strategy chosen in the second period. However, given only two periods and preferences as in Figures 3 and 4, any strategy choosing $\mathrm{L}$ in the second period is inferior to one using $\mathrm{J}$ in that period, as $\mathrm{J}$ gives a better outcome in the second period, and the only advantage of using $\mathrm{L}$ is for better future outcomes. Thus, we need only compare $(\mathrm{L}, \mathrm{J})$ with $(\mathrm{J}, \mathrm{J})$.

$(L, J)$ yields outcome $M$ iu the first period. In the second period, it yields $G(M)^{\prime}$ with probability $p_{L}$ or else $G(M)$ with probability $1-p_{L}$. Because legislative strategies are typically more costly than judicial strategies, I add a cost term. Let $C_{L}$ be the cost of a legislative strategy in the first period, and $C_{J}$ be the cost of a judicial strategy, with $C_{L}>C_{J}>0$. Activists care about both cost and outcome. They want costs to be low, and they want the outcome to be as far to the left as possible, which is indicated by a smaller number given the ordinary orientation of a

134. $\mathrm{C}$ is unchanged to reflect the slower movement in Court preferences in response to political pressures. Figure 4 does not contain SQ because $S Q$ is relevant only for a legislative strategy. Figure 4 represents second-period preferences, and, as we shall see, given these preferences there is no reason to pursue a legislative strategy in the final period. If one wanted to include $S Q$ in Figure 4, it would be the outcome achieved in the first period, i.e., either $G(M)$ (if activists follow the judicial strategy) or $M$ (if they follow the legislative strategy).

135. We can think of the shift as occurring or not based on a draw after the first period is finished, with $\mathrm{p}_{\mathrm{L}}$ and $\mathrm{p}_{\mathrm{J}}$ reflecting the probability of the shift occurring. This is a game with uncertainty but perfect information, since at the time the activists choose an initial strategy, they do not know the outcome of the draw; by the time the activists make their choice in period 2, they know what has happened. See RASMUSEN, supra note 11, at 51-52.

136. One could also think of strategy $L$ as leading to a bigger shift in preferences leftward, rather than merely a higher probability of a shift. The probability approach captures the idea simply. 
number line. ${ }^{137}$ Suppose costs and position achieved are measurable in comparable units, and that activists discount the future in a way measured by the discount factor $\delta$, such that $0<\delta<1$. ${ }^{138}$ The expected present value to the activists from choosing $(\mathrm{L}, \mathrm{J})$ is $\mathrm{M}+\mathrm{C}_{\mathrm{L}}+\delta\left[\mathrm{p}_{\mathrm{L}}{ }^{*} \mathrm{G}(\mathrm{M})^{\prime}+\right.$ $\left.\left(1-p_{L}\right)^{*} G(M)\right]$. (J, J) yields $G(M)$ in the first period and $G(M)$ ' with probability $p_{\mathrm{J}}$ in the second, or else $\mathrm{G}(\mathrm{M})$. The expected present value is thus $\mathrm{G}(\mathrm{M})+\mathrm{C}_{\mathrm{J}}+\delta\left[\mathrm{p}_{\mathrm{J}}^{*} \mathrm{G}(\mathrm{M})^{\prime}+\left(1-\mathrm{p}_{\mathrm{J}}\right) * \mathrm{G}(\mathrm{M})\right]$.

In comparing these two payoffs, activists will choose the strategy which gives the smallest expected payoff-remember, activists are trying to move to the left, so here smaller is better. We see that $(\mathrm{L}, \mathrm{J})$ leads to a smaller payoff if and only if

$$
M-G(M)+C_{L}-C_{J}<\delta\left[\left(G(M)-G(M)^{\prime}\right)\left(p_{L}-p_{J}\right)\right]
$$

The left term represents the gain in the first period froin using $\mathrm{J}$ rather than L, since the Court will go to the left of Congress on preferences such as in Figure 3, and activists will incur the lower cost $C_{\mathrm{J}}$. The right hand side represents the gain in the second period from using $L$ rather than J. ${ }^{139}$ It depends on three things: how big the potential shift in preferences is, how much more likely $L$ is than $J$ to cause the shift, and how much one discounts the future. ${ }^{140}$

Inequality (1) thus embodies a tradeoff between a judicial and a legislative strategy. In times when the Court is better-disposed to civil rights, a judicial strategy may lead to better short-term results. It also is a less costly strategy for activists to pursue. On the other hand, a legislative strategy may lead to greater mobilization of civil rights supporters and greater changes in public values. In turn, these factors affect institutional preferences, leading to better results in the long mn. Which strategy is best depends on how much more the legislative strategy affects

137. Thus, the activists are modeled as striving to minimize their objective function, not to maximize it. This may seem counterintuitive to some, but altering the model to picture them as maximizing would cause confusion in interpreting movement along the line representing their preferences. The problem disappears in modeling conservative activists who want to move to the right. More generally, economic reasouning is not about maximization, but rather about optimization. Sometimes economic models picture persons as striving to maximize, for example, utility or profit. Other times, though, they try to minimize, as in discussions of costs. In a two-person zero-sum game, one player tries to maximize and the other to minimize.

138. The discount factor reflects how strongly activists value the second period relative to the first. With $\delta=0$, they do not value the second period at all. With $\delta=1$, they value the two periods equally.

139. Note that, as modeled, it is quite important that $M$ does not equal $G(M)$, i.e., that committee preferences differ from congressional preferences, a point disputed in the literature. However, one could achieve similar results by modeling the House and Senate as having different preferences.

140. A super-strategic Court might choose a far-left strategy to provoke legislation if it thinks that inequality (1) is satisfied. 
future preferences. It also depends on the discount factor, which may reflect not only pure time preference, but also uncertainty about the future, so that if one is very unsure about the future impact of present actions, one might be less likely to give much weight to the kind of factors this paper discusses.

Of course, this model is extremely simple and could be complicated in a number of ways. For example, one could add multiple periods. In a multi-period model, judicial preferences may shift with a lag as Congressional and Presidential preferences shift. Judicial preferences may also shift as a result of a judicial strategy. The amount of the preference shift, as well as its probability, might depend on the strategy followed. One could have a range of possible future preferences with associated probabilities, rather than the two simple possible future states presented here. The probabilities and degree of shift could be made to depend explicitly on the sorts of factors discussed in Part IV, leading to a much richer model. In particular, the probability of a shift may depend also on the result achieved in period one, independent of which strategy was followed.

More subtly, I have presumed an either/or choice between a judicial and a legislative strategy. ${ }^{141}$ Life, naturally, is more complicated. An organization like the NAACP continually engages in both judicial and legislative strategies. Probably some optimal mix of the two works better than either one on its own. The model should be taken as a very stylized argument which illustrates some of the tendencies of the different approaches. My point, then, is not that civil rights groups should eschew going to court altogether, but rather that they may have overemphasized a judicial approach and devoted too little effort to other options.

If activists can choose some of both strategies, the question arises as to whether they are substitutes or complements. In some ways, at least, they are substitutes. The time and money spent on fundraising for and paying a trial lawyer's fee cannot be used to pay for a lobbyist. In some ways, though, and perhaps over a longer time period, the strategies are complementary. For instance, lesbian and gay activists followed a judicial strategy in Baehr $v$. Lewin to challenge the marriage law in Hawaii. ${ }^{122}$ The resulting controversy has activated both friends and foes in state legislatures around the country, creating more legislative activism on the issue than there would have been without the court case. For instance, the progress of a bill to declare same-sex marriage against public policy in California has generated a letter-writing and phone campaign opposing it. Evan Wolfson of the Lambda Legal Defense

141. Mass action has dropped out of the picture because its characteristics are much like those of legislative action for purposes of this model. But see infra Part VI.

142. See Baehr v. Lewin, 852 P. 2d 44 (Haw. 1993). 
Fund, which is heavily involved in Baehr, says that by necessity activists on this issue must pursue it both in the courts and through other forms of political action. ${ }^{143}$ To the extent that the strategies are complements, the questions of this Comment become more complicated.

Also, the model, and much of this Comment, assumes that activists can choose which strategy to follow. Plaintiffs in civil rights cases need not acquire the approval of the NAACP Legal Defense Fund before going to court, however. Cases raising important questions can reach the Supreme Court without the major activist groups planning or even desiring it. Of necessity, these groups may then become involved to obtain a positive outcome, even if they would prefer no court outcome. Similarly, though much less frequently, legislators may introduce bills without consulting with political groups. Again, the groups may need to pursue legislation that they would not have chosen to set in motion themselves.

Despite all the caveats, this Part's model does bring out some important points. In thinking about the Court/Congress/President interaction, one must consider the long-run effects of present strategies. In some circumstances, a judicial approach may have a better short-run outcome, but a legislative or mass action approach will have a stronger long-run effect, because these strategies do more to affect underlying political mobilization and values. It becomes important, then, to try to predict the long-run effects of different approaches. This will be quite difficult, and the answers may be very situation-specific. In the next Part, I revisit the Civil Rights Act of 1991 and see what light the questions we have discussed in Parts IV and V shed on the events surrounding the Act and on our current situation.

\section{VI}

\section{The Civil Rights Act of i99i, Redux, and the Present Situation}

According to Eskridge, the cases overruled in the 1991 Civil Rights Act illustrate that the Court has not played the strategic political game very well in recent years. ${ }^{144}$ Because of the Court's positioning, many of its decisions could easily have been overturned by the Act. ${ }^{145}$ The inclusion of provisions overturning Wards Cove Packing Co. $v$. Atonio, ${ }^{146}$ and perhaps a few other elements of the Act, made the vote

143. See Evan Wolfson, Crossing the Threshold: Equal Marriage Rights for Lesbians and Gay Men and the Intra-Community Critique, 21 N.Y.U. REv. L. \& Soc. Change 567, 612 (1994).

144. See Eskridge, supra note 9, at 683-84.

145. An alternative explanation would be that the Court sees itself as a naive agent of the enacting legislatures and will interpret laws as close to the original meaning as possible at the cost of being overturned by the present legislature. See John A. Ferejohn \& Barry R. Weingast, A Positive Theory of Statutory Interpretation, 12 INT'L REv. L. \& ECON. 263, 268 (1992).

146490 U.S. 642 (1989). 
close, but after the close call of 1990 , the Act did pass in 1991. The model presented im the last Part suggests two other possibilities. First, the Court's decisions may actually have strengthened civil rights support by forcing activists to pursue a legislative strategy. Alternatively, the decisions may have led to more conservative public attitudes in the long run. The first point appears more likely to be correct.

On the one hand, the Court setbacks may have been a blessing in disguise for civil rights advocates. The myriad court losses in 1989 forced civil rights advocates to go to the legislature, as had happened repeatedly in the previous decade or two. ${ }^{147}$ This was not mass action, but rather legislative lobbying. A coalition of civil rights groups gathered to pressure Congress to overrule the decisions. Action also occurred at the state level; in Massachusetts, the Boston Bar Association, the Massachusetts Superior Court Bench, the Civil Liberties Unions, the Lawyers Committee for Civil Rights Under Law, and lawyers from Northeastern University drafted a bill overturning Patterson v. McLean Credit Union ${ }^{148}$ at the state level. ${ }^{149}$

Lobbying also affects public beliefs and mobilization. Here, the effect of Patterson may have been quite different from that of Wards Cove. Because Patterson involved a relatively technical issue, it would be quite surprising if it had much of an impact on mass opinion. It may have spurred some business opposition to overturning the decision, but otherwise probably had little positive or negative effect on public opinion. The response to Patterson and the other fairly narrow cases probably helped the civil rights movement, because failure in the judicial arena encouraged civil rights groups to work effectively in the halls of Congress and reminded politicians of the clout of an important interest group. These decisions probably did little to stir opposition to civil rights. Moreover, the Act's provisions on jury trials and compensatory and punitive damages advanced the laws beyond what the Court could have done.

On the other hand, Wards Cove likely had a different effect. Both the Court and President Bush managed to raise the issue of quotas in connection with it, and that word can inspire powerful emotions in American discussions of race. The Court argued that allowing a statistical disparity to constitute a prima facie showing of discrimination, combined with a strict business necessity requirement in defense, would

147. See Eskridge, supra note 9, at 617-41.

148491 U.S. 164 (1989).

149. See Ian F. Haney López, Recent Developments, 25 HARv. C.R.-C.L. L. Rev. 147, 151 (1990). 
force businesses to impose quotas in order to avoid losing lawsuits. ${ }^{150}$ Republicans and the Bush Administration latched onto this in explaining their opposition to the 1990 and 1991 bills, and the issue thus received much public exposure. ${ }^{151}$

Opponents of the Act lost the battle, mostly, ${ }^{152}$ but the war is not over. For many years, the public has opposed quotas, and has been at best uneasy about affirmative action generally. Supporters have been remarkably successful at avoiding political battles over the issue, but their luck seems to be running out. The California Civil Rights Initiative of November 1996 will eliminate state-run affirmative action programs if it survives constitutional challenge. ${ }^{153}$ Other states are likely to follow with initiatives.

The Rehnquist Supreme Court has looked with disfavor on affirmative action programs, instead shaping an individualistic vision of racial justice. Wards Cove is an example of this, along with many constitutional cases invoking the Equal Protection Clause. ${ }^{154}$ The Court's individualistic approach seems consistent with the prevailing public opinion. It is very hard to say to what extent the Court reflects that prevailing opinion and to what extent the Court shapes it. To the extent that the Court is shaping opinion through decisions like Wards Cove, the Court's short-term loss in the 1991 Act may ultimately be less important than the long-run victory of the Court's views on civil rights in American society and law. As argued in Part IV, however, the effects of Court decisions on public opinion are probably less strong than the effects generated by other strategies.

What does the theory say about the effect of different strategies in the current political climate? Today, the President is to the left of Congress and the Court. It is difficult to say whether Congress or the Court is more conservative, but, on civil rights issues, the Court seems more actively conservative than Congress has been, at least as of this

150. See Wards Cove, 490 U.S. at 652; see also Dansicker, supra note 48, at 38 (arguing that goals will be seen as quotas if the burden placed on employers to justify their employment choices is set too high).

151. See Dansicker, supra note 48 , at $42-48$.

152. "Business necessity" was left undefined in the 1991 Act, so the battle continues in the courts. See supra note 56 and accompanying text. The question of retroactivity was also left open. Furthermore, $\S 106$ of the Act makes it an unlawful employment practice to use different cutoff points by race in employment-related tests or to adjust the scores by race. This restricts certain forms of affirmative action.

153 On April 8, 1997, a three-judge panel of the Ninth Circuit Court of Appeals vacated a district court preliminary injunction enjoiniug California from enforcing the Proposition. See Coalition for Economic Equality v. Wilson, 110 F.3d 1431 (9th Cir. Apr. 8, 1997). The petition for rehearing and the suggestion for rehearing en banc were denied. See Coalition for Economic Equality v. Wilson, 1197 WL 528335 (9th Cir. Aug. 21, 1997).

154. See, e.g., Richmond v. J.A. Croson Co., 488 U.S. 469 (1989). 
writing. Thus, a plausible picture of relative preferences today may be as in Figure 5.

\begin{tabular}{ccccccc}
\hline & $\perp$ & 1 & & $\mid$ & $\mid$ & $\perp$ \\
\hline$P$ & $V$ & $S Q$ & $M$ & $C$ & $G$ & $G(M)$
\end{tabular}

Figure 5

Were activists to follow a judicial strategy, the Court could choose any point between $V$ and $G(M)$. To the right of $G(M)$, the committee would introduce a bill, Congress would pass $M$, and the President would sign it. Between $G(M)$ and $M$, the committee would block any bill from being introduced, so the Court's decision would stand. Between $M$ and $\mathrm{V}$, the committee would introduce a bill and Congress would pass a version of it, but the President would veto it and Congress could not override, so the Court decision would stand. To the left of $V$, the committee would introduce a bill, and Congress would pass something to the right of $V .{ }^{155}$ With preferences as shown, the Court would choose its ideal point $\mathrm{C}$ in interpreting that statute. It may also be possible that such a move to the right of the status quo has a probability of making future preferences more conservative. If so, a judicial strategy today has bad short- and long-term consequences for civil rights activists.

If activists instead pursue a legislative strategy, the result would be the status quo. The President would veto any move by Congress to the right, and Congress could not override the veto. This may explain why the present Congress has been so inactive on civil rights issues.

Under the current configuration, a legislative strategy by pro-civil rights activists does not improve upon the status quo, and a judicial strategy actually makes things worse. This suggests a way of introducing mass action into the formal model. Mass action may be most effective, not in changing the current legal status quo, but rather in affecting future preferences of the political actors. Thus, mass action would yield $S Q$ in the first period, with the high cost $C_{M}>C_{L}>C_{J}$, but would yield greater probability of shifting preferences left in period $2, \mathrm{p}_{M}>\mathrm{p}_{\mathrm{L}}>\mathrm{p}_{\mathrm{J}}$. There would thus be a tradeoff between higher cost and better future outcome. Note that if SQ were to the left of V, congressional action (like judicial action) would make matters worse, and mass action would actually lead to the best results. This may well represent the dilemma facing civil rights activists today. Going to court creates the risk that the case will reach the Supreme Court, and a bad precedent will be set. Going to Congress is at best futile and might actually help provoke Congress to

155. How far right depends on how far to the left of $V$ the Court's decision is. The further the Court is to the left, the further right is the bill Congress would pass. 
pass a bill worsening the law. Under such conditions, it is best to stay out of the courts and Congress and to focus on grassroots mass action, or perhaps visible action aimed at gaining the support of the President, a potentially important ally and opinion leader. On the other hand, mass action may be beyond the limited resources of the current movement.

\section{CONCLUSION}

I have analyzed dynamic statutory interpretation in civil rights cases, starting with Eskridge's work and expanding upon it. I have made Eskridge's work more dynamic by considering the effects that present political behavior may have on the future preferences of Congress, the President, and the Court. I should stress that this Comment has focused on positive, predictive questions concerning the Court and civil rights cases. Insofar as it has a normative side, it has been from the perspective of activists asking how to pursue their goals, not from the perspective of judges asking how best to interpret a statute.

The middle section of this essay considered various ways in which different kinds of present political behavior-litigation, legislative lobbying, and mass action-could affect future institutional preferences. Different kinds of political action may affect mobilization and public opinion differently, and may have different effects on the preferences of the various branches of government. Mass action has the strongest effects, and judicial strategy the weakest.

Parts V and VI summed up this analysis in a simple model and applied it to the events surrounding the Civil Rights Act of 1991 and the current situation. Even when the Court is more receptive to civil rights groups than Congress, activists may face a tradeoff between short-term gains from using the Court and a longer-run weakening of the movement if they thereby fail to keep up political pressure at the grassroots level. When, as now, the Court is more hostile to civil rights than Congress, not only do activists in court risk a short-term loss, but that loss will be compounded as the Court helps shape public opinion in a more conservative direction.

I have focused on racial politics, but the argument can be generalized to other contexts. It might well apply to other movements focused on civil rights-feminist groups and lesbian, gay, and bisexual groups, for instance. It might also be interesting to apply the method of analysis developed in this Comment to the environmental movement. My framework would seem to apply less well to areas of the law that do not involve potential collective action by large-scale social movements.

Finally, even in the racial context, I have avoided major relevant questions. Throughout this Comment, I have assumed that the ultimate goal is to achieve desirable statements of the law. Presumably, though, 
the ultimate goal is to achieve racial justice, which will involve improving the political, social, and economic position of blacks and other racial minorities. Good laws may not meet that end for at least two reasons. First, laws must be implemented. One critique of court-based strategies has been that even if courts come through with sympathetic decisions, courts are not good at implementing general social policy on their own. ${ }^{156}$ Second, for some problems, better laws, or even better government policy generally, may not be the answer, or at least not the whole answer.

To the extent that these points are true, they will affect the strategies discussed in this Comment. Civil rights organizers will notice that gains in court may not translate into substantial social gains. So long as activism thereafter continues to focus on courts, supporters will lose interest, and political pressure for change will decline. Persons who care about civil rights in the U.S. must thus ask what has gone wrong politically, socially, and economically since the highs of the sixties. Activists must constantly ask what kind of individual and collective action is best suited to reaching the goal of a racially egalitarian society.

That is a truly hard question.

156. See ROSENBERG, supra note 8, at 3. 